\title{
Dissemination of a single Vibrio cholerae clone in cholera outbreaks during 2005 in Iran
}

\section{Correspondence \\ M. R. Pourshafie \\ pour@pasteur.ac.ir}

Received 7 February 2007

Accepted 27 July 2007

\author{
M. R. Pourshafie, ${ }^{1}$ B. Bakhshi, ${ }^{1}$ R. Ranjbar, ${ }^{2}$ M. Sedaghat, ${ }^{1}$ \\ N. Sadeghifard, ${ }^{3} \dagger$ J. Zaemi Yazdi, ${ }^{3} \ddagger$ M. Parzadeh ${ }^{1}$ and J. Raesi ${ }^{1}$ \\ ${ }^{1}$ Department of Bacteriology, Pasteur Institute of Iran, Pasteur Avenue, Tehran, Iran \\ ${ }^{2}$ Molecular Biology Research Center, Baqiyatallah University of Medical Sciences, Tehran, Iran \\ ${ }^{3}$ Department of Bacteriology, University of Tehran, Tehran, Iran
}

\begin{abstract}
In this study, 50 Vibrio cholerae $\mathrm{O} 1$ serotype Inaba isolates were collected during several cholera outbreaks throughout Iran during the summer of 2005. The results of antibiotic susceptibility testing showed that $86,84,84$ and $82 \%$ of the isolates were resistant to streptomycin, chloramphenicol, co-trimoxazole and tetracycline, respectively. The strains were genotyped using randomly amplified polymorphic DNA (RAPD), PFGE and ribotyping techniques. PCR showed that 100,98 and $98 \%$ carried the $c t x$, zot and ace genes, respectively. Biochemical fingerprinting of the isolates using the PhenePlate (PhP) system showed a low diversity index level (0.755), suggesting that the strains were highly homogeneous. Among the strains, 100 and $96 \%$ showed an identical ribotype and PFGE patterns, respectively. The two isolates showing different PFGE patterns also exhibited discrete PhP types. RAPD was able to discriminate the isolates into six distinct groups, suggesting some genetic dissimilarity was present among the strains. These ribotyping, PFGE and PhP techniques revealed the clonal dissemination of a single $V$. cholerae strain throughout Iran in 2005.
\end{abstract}

\section{INTRODUCTION}

Vibrio cholerae $\mathrm{O} 1$ causes diarrhoeal disease that afflicts thousands of people annually (Faruque et al., 1998). In the past, the prevalence of $V$. cholerae resistant to antibiotics was low and routine susceptibility testing was not recommended (Dalsgaard et al., 2000). However, reports of $V$. cholerae strains resistant to commonly used antibiotics are appearing with increasing frequency worldwide (Garg et al., 2000, 2001). Outbreaks of cholera due to the El Tor O1 serotype with changeable antibiotic-resistant patterns are occurring periodically in Iran also, causing public health problems.

Previously, we described the clonal diversity of clinical isolates of $V$. cholerae obtained during 1998 (Pourshafie et al., 2000) and 2000 (Pourshafie et al., 2002). Ribotyping analysis of the 16s and 23s rRNA genes of these strains suggested the presence of a predominant $V$. cholerae ribotype in Iran. The present study was designed to characterize isolates obtained during outbreaks in 2005 in several provinces in Iran. We present a detailed study, including genotypic and phenotypic characteristics, of a

tPresent address: University of Medical Sciences of Ilam, llam, Iran. $\ddagger$ Present address: University of Medical Sciences of Yazd, Yazd, Iran. Abbreviations: CT, common type; PhP, PhenePlate; RAPD, randomly amplified polymorphic DNA. predominant and new $V$. cholerae strain emerging in Iran, which was not observed in the previous years.

\section{METHODS}

Bacterial isolates. Faecal specimens were collected from patients suspected of having cholera in the summer of 2005 in Iran. The samples were collected with sterile swabs, which were placed in CaryBlair transport medium. Alkaline peptone water was used for the enrichment of $V$. cholerae and bacteria were then isolated on thiosulphate-citrate-bile salt-sucrose agar plates (Farmer \& Hickman-Brenner, 1992). The strains were isolated from different provinces in Iran, including Qom (13 samples), Golastan (14 samples), Zahadan (8 samples) and Tehran (15 samples). Identification of the clinical strains of $V$. cholerae isolates and $\mathrm{O}$ serotyping was done by detailed biochemical tests and agglutination by antiserum.

Antimicrobial susceptibility testing. Antibiotic susceptibility was tested by the standard disc diffusion technique according to NCCLS (2001) guidelines with the following antibiotics: gentamicin $(10 \mu \mathrm{g})$, polymyxin B $(300 \mathrm{U})$, doxycycline $(30 \mu \mathrm{g})$, ciprofloxacin $(5 \mu \mathrm{g})$ and tetracycline $(30 \mu \mathrm{g})$ (purchased from Difco) and streptomycin $(5 \mu \mathrm{g})$, ampicillin $(10 \mu \mathrm{g})$, erythromycin $(15 \mu \mathrm{g})$, furazolidone $(100 \mu \mathrm{g})$, chloramphenicol $(30 \mu \mathrm{g})$ and co-trimoxazole $(25 \mu \mathrm{g})$ (purchased from Becton Dickinson).

Ribotyping. Ribotyping was performed as described previously (Pourshafie et al., 2000). Briefly, DNA extracted from V. cholerae isolates was cleaved by the restriction endonuclease BglI (Roche Diagnostic). The fragments were separated by agarose gel 
electrophoresis and then transferred onto nylon membrane using an alkali blotting procedure with a vacuum blotter. Hybridization was performed with probes labelled with digoxigenin-11-dUTP. The membranes were then visualized by the addition of alkaline phosphate-conjugated anti-digoxigenin antibody (Roche Diagnostic), and 5-bromo-4-chloro-3-indolyl phosphate substrate and nitro blue tetrazolium.

PCR for toxin genes. The primers used PCR of genes encoding cholera toxin $(c t x \mathrm{~A})$, accessory cholera enterotoxin (ace) and zonula occludens toxin $(z o t)$ were as described previously (Pourshafie et al., 2000). DNA was extracted and PCR carried out in a reaction mixture containing $20 \mu \mathrm{l}$ sterile water, $2.5 \mu \mathrm{l} 10 \mathrm{x}$ Taq polymerase buffer, $0.3 \mu \mathrm{l}$ dNTPs $(10 \mathrm{mM}), 0.5 \mathrm{U}$ Taq DNA polymerase, 25 pmol each primer. The cycling conditions were as follows: preincubation at $94{ }^{\circ} \mathrm{C}$ for $5 \mathrm{~min}, 30$ cycles of $1 \mathrm{~min}$ at $94{ }^{\circ} \mathrm{C}$ for denaturation, $1 \mathrm{~min}$ at $64{ }^{\circ} \mathrm{C}$ for annealing, $2 \mathrm{~min}$ at $72{ }^{\circ} \mathrm{C}$ for elongation, and incubation at $72{ }^{\circ} \mathrm{C}$ for $3 \mathrm{~min}$ for final elongation.

Random amplification. The randomly amplified polymorphic DNA (RAPD) technique used the primers ARB11 5'-CTAGGACCGC-3' and AP-PGO5 5'-AGCCCAGCTATGAAC-3' (Killgore \& Kato, 1994). The cycling conditions for RAPD-PCR were as follows: pre-incubation at $94{ }^{\circ} \mathrm{C}$ for $5 \mathrm{~min}$, and 40 cycles of $30 \mathrm{~s}$ at $94{ }^{\circ} \mathrm{C}, 1 \mathrm{~min}$ at $40{ }^{\circ} \mathrm{C}, 72{ }^{\circ} \mathrm{C}$ for $1 \mathrm{~min}$, and a final incubation for $10 \mathrm{~min}$ at $72{ }^{\circ} \mathrm{C}$.

Biochemical fingerprinting with the PhenePlate (PhP) system. $V$. cholerae isolates were typed with the PhenePlate $(\mathrm{PhP})$ system, a rapid, semi-automated and computerized biochemical method using PhP-RV plates (PhPlate). These microplates are used to measure the kinetics of bacterial metabolism of 11 substrates, which are specifically chosen to differentiate between isolates of Vibrio. Briefly, one bacterial colony was inoculated in $\mathrm{PhP}$ suspending medium containing $0.011 \%(\mathrm{w} / \mathrm{v})$ bromothymol blue $(\mathrm{pH} 8), 0.05 \%(\mathrm{w} / \mathrm{v})$ proteose peptone, $2 \%(\mathrm{w} / \mathrm{v})$ sodium chloride and $0.0016 \mathrm{M}$ phosphate buffer, in the first column of the pre-prepared $\mathrm{PhP}$ plate. The bacterial suspension was then dispensed to the plate wells containing dehydrated substrates, and incubated for 16, 40 and $64 \mathrm{~h}$. The biochemical fingerprints of isolates were compared pair-wise and the similarity between each pair was calculated as the correlation coefficient. This yielded a similarity matrix and accordingly a dendrogram. The level of identity between the isolates was defined as the mean of the correlation coefficients obtained between these duplicate assays minus two SDs of this mean. All the data processing, including optical readings and calculations of correlation coefficients, as well as clustering and printing of dendrograms, was performed with PhP software (Ansaruzzaman et al., 1996; Kühn et al., 1990).

PFGE. A Pulsenet (www.cdc.gov/pulsenet) standardized protocol was used for subtyping of $V$. cholerae isolates. Briefly, bacteria from the surface of the culture plates were transferred into cell suspension buffer (100 mM tris, $100 \mathrm{mM}$ EDTA, $\mathrm{pH}$ 8.0) after which they were adjusted to absorbance values of $0.8-1.0$ at a wavelength of $610 \mathrm{~nm}$. Agarose plugs were prepared by mixing equal volumes of the adjusted bacterial suspension with $1.0 \%$ SeaKem gold agarose (Cambrex) and $20 \mu$ proteinase $\mathrm{K}\left(20 \mathrm{mg} \mathrm{ml}^{-1}\right.$ stock). Cells in the agarose plugs were lysed by treatment with a lysis solution $[50 \mathrm{mM}$ tris, $50 \mathrm{mM}$ EDTA (pH 8.0), $1 \%$ sarcosine, $0.5 \mathrm{mg}$ proteinase $\mathrm{K} \mathrm{ml}^{-1}$ ] for $1 \mathrm{~h}$ at $54{ }^{\circ} \mathrm{C}$. Washing was performed in six stages, twice with sterile ultrapure water and four times with TE buffer $(10 \mathrm{mM}$ tris, $1 \mathrm{mM}$ EDTA, pH 8.0). One section of the plug was equilibrated with an enzyme buffer, placed in $200 \mu \mathrm{l}$ fresh buffer containing $40 \mathrm{U}$ NotI (Roche Diagnostic) and incubated for $4 \mathrm{~h}$. Salmonella choleraesuis serotype Branderup H9812 (www.cdc.gov/pulsenet) plugs digested with $\mathrm{Xba \textrm {I }}$ for $2 \mathrm{~h}$ at $37^{\circ} \mathrm{C}$ were used as DNA molecular mass size markers. The electrophoresis conditions consisted of a two-block program: block I with an initial switch time (IST) of $2 \mathrm{~s}$ to final switch time (FST) of $10 \mathrm{~s}$ and a run time of $13 \mathrm{~h}$; block 2 with an IST of $20 \mathrm{~s}$ to a FST of $25 \mathrm{~s}$ and a run time of $6 \mathrm{~h}$. Both blocks were run with a gradient of $6.0 \mathrm{~V} \mathrm{~cm}^{-1}$ and an included angle of $120^{\circ}$ at $14{ }^{\circ} \mathrm{C}$.

\section{RESULTS AND DISCUSSION}

\section{Genotyping analysis}

Ribotyping was one of the first fingerprinting techniques to be successfully used in the taxonomy of Vibrio spp. (Thompson et al., 2004) and a standardized ribotyping scheme has been proposed as a tool for epidemiological studies of $V$. cholerae (Popovic et al., 1993). Fig. 1 shows the ribotype representatives of the isolates obtained during 2005. All strains showed a single ribotype pattern that had not been previously observed in Iran (Pourshafie et al., 2000, 2002). The appearance of this new ribotype pattern suggests that the isolates may have gone through rRNA operon rearrangement (Lan \& Reeves 1998).

Representative patterns from RAPD profiling using arbitrary primers are shown in Fig. 2. Six different RAPD patterns were observed among the strains. The RAPD pattern labelled as one was the predominant pattern, containing $36 \%$ of the isolates. This was followed by RAPD patterns five and six with $23 \%$ of the isolates each. The least common RAPD patterns were two and three representing about $4.5 \%$ of the isolates. Further analysis showed several RAPD patterns in isolates that were obtained from a single province. Our data are indicative that PCR amplification of random fragments of genomic DNA using arbitrary 10-15-mer primers might have a substantial discriminatory power.

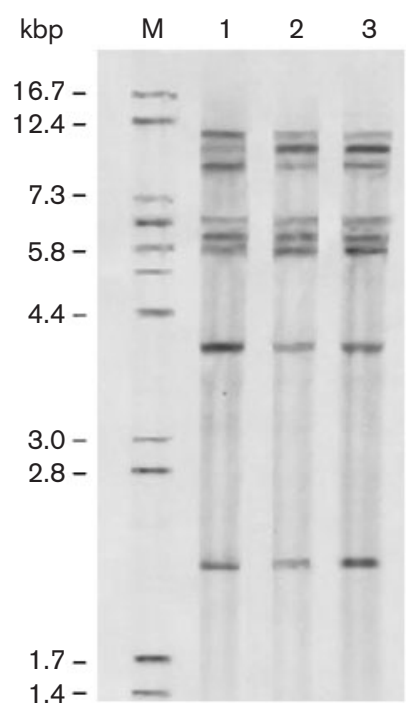

Fig. 1. Ribotype analysis of $V$. cholerae DNA digested with Bg/l restriction endonuclease. Molecular marker sizes are indicated on the left. Lanes $1-3$ are the representative ribotypes showing a single pattern for all isolates from 2005. 


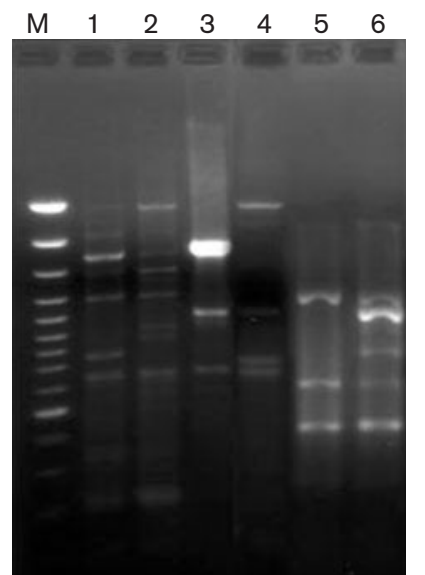

Fig. 2. Representative RAPD patterns, showing six different patterns. M, Marker.

A single predominant (96\%) PFGE pattern was observed among the isolates (Fig. 3). Of the $50 \mathrm{~V}$. cholerae, only 2 isolates showed distinct and completely different PFGE patterns (Fig. 3, lanes 1 and 2). One of these isolates did not harbour zot and ace genes (Fig. 3, lane 2). By PCR, all strains carried ctx genes, and zot and ace genes were present in 49 of the 50 isolates.

\section{Antibiotic susceptibility}

Widespread antibiotic resistance in $V$. cholerae was unheard of before 1977, but multiple antibiotic-resistant $V$. cholerae have emerged as a major problem worldwide. $V$. cholerae strains resistant to tetracycline, ampicillin, kanamycin, streptomycin, sulphonamides, trimethoprim and gentamicin have been reported frequently (Sack et al., 2004). Table 1 shows the antibiotic susceptibility patterns of Iranian strains isolated in 2005. The highest frequency of resistance was observed with streptomycin (86\%), followed by co-trimoxazole and chloramphenicol ( $84 \%$ each). Isolates could be grouped on the basis of their antibioticresistance patterns into 17 categories (Fig. 4). Resistance to furazolidone $(62 \%)$ was only observed in strains from Zahadan province. Resistance to tetracycline was also significant $(82 \%)$ (Table 1$)$, in contrast to reports that

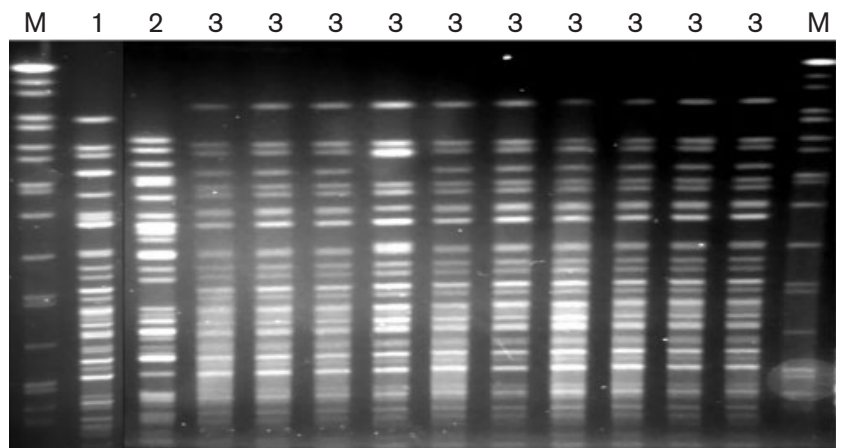

Fig. 3. Representative PFGE patterns of the $50 \mathrm{~V}$. cholerae isolates. 1 , composed of 1 isolate; 2 , composed of 1 isolate; 3 , composed of 48 isolates; $\mathrm{M}$, marker.

suggested tetracycline-resistant $V$. cholerae $\mathrm{O} 1$ isolates in epidemics or outbreaks are usually uncommon in Malaysia (Chen et al., 2004) and other countries, such as Thailand and Laos where few tetracycline-resistant isolates have been reported (Kondo et al., 2001; Iwanaga et al., 2000). In previous years, however, we also observed that only a small number of the $V$. cholerae isolates in Iran were resistant to tetracycline (Pourshafie et al., 2002).

In the present study, most of the isolates were resistant to streptomycin, co-trimoxazole and chloramphenicol. Resistance to these antibiotics has been shown to be encoded by genes on a conjugative SXT transposon (Hochhut et al., 2001; Amita et al., 2003). It is therefore possible that this transposon was extensively disseminated among our isolates. Furthermore, the $\mathrm{PhP}$ analysis showed (Fig. 4) that 19 out of 20 isolates had identical biochemical characteristics [labelled as common type (CT)1] and were resistant to co-trimoxazole, streptomycin and chloramphenicol. Interestingly, these isolates were obtained from different provinces in Iran. This finding may suggest that these strains have vertically acquired the SXT transposon and spread in different geographical areas.

\section{PhP analysis}

With an identity level of 0.975 , the PhP system showed 1 major cluster comprising 48 isolates $(90 \%)$ and 2 isolates

Table 1. Antibiotic-resistance patterns of $V$. cholerae isolated from different provinces in Iran

Definitions of the abbreviations are given in Fig. 4.

\begin{tabular}{|lrrrrrrrrrr|}
\hline $\begin{array}{l}\text { Province (no. of strains } \\
\text { tested) }\end{array}$ & C (\%) & SXT (\%) & TE (\%) & E (\%) & ST (\%) & AP (\%) & F (\%) & PB (\%) & DO (\%) & GM (\%) \\
\hline Tehran (15) & 66 & 60 & 87 & 0 & 67 & 27 & 0 & 87 & 7 \\
Qom (13) & 100 & 100 & 92 & 0 & 100 & 40 & 0 & 85 & 0 & 0 \\
Golestan (14) & 86 & 93 & 71 & 14 & 93 & 43 & 0 & 71 & 7 & 0 \\
Zahadan (8) & 100 & 100 & 87 & 0 & 100 & 75 & 62 & 75 & 0 & 0 \\
\hline
\end{tabular}


Antibiogram

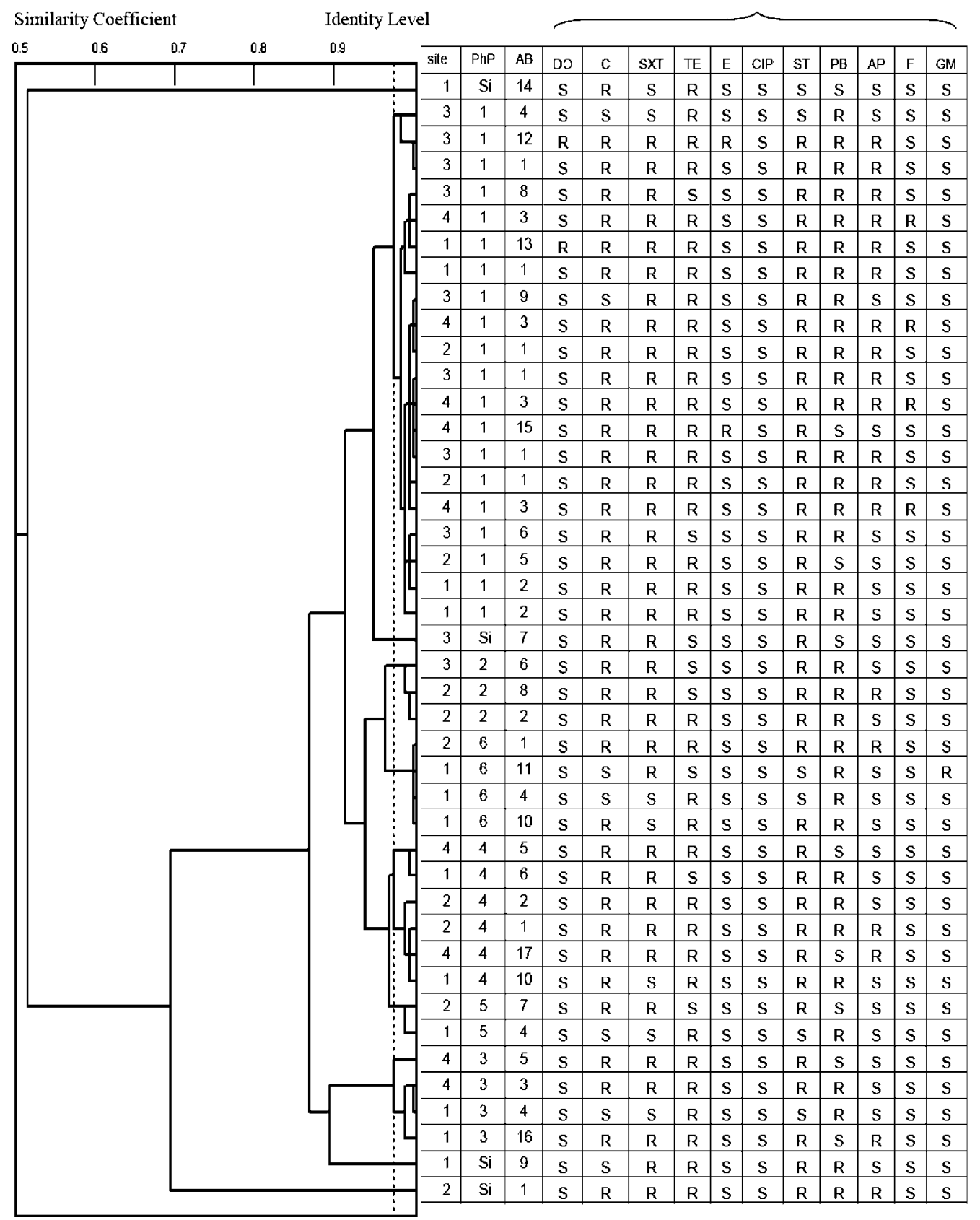

Fig. 4. A UPGMA dendrogram showing the cluster analysis of biochemical fingerprinting data for $50 \mathrm{~V}$. cholerae isolates. $\mathrm{AB}$, antibiotic-resistance pattern; DO, doxycycline; C, chloramphenicol; SXT, co-trimoxazole; TE, tetracycline; E, erythromycin; CIP, ciprofloxacin; ST, streptomycin; PB, polymyxin B; AP, ampicillin; F, furazolidone; GM, gentamicin. The sites (provinces) where the isolates were obtained are indicated: 1, Tehran; 2, Qom; 3, Golestan; 4, Zahadan. The PhP type (biochemical phenotype) of each isolate is indicated as belonging to a single type $(\mathrm{Si})$ or a CT numbered from 1-6.

each as a single type (the first and last isolates in the dendrogram) (Fig. 4). Detailed analysis of the UPGMA dendrogram showed six CTs. PhP analysis showed a major CT1 with 20 isolates (46.5\%) followed by CT4 with 6 isolates $(14 \%)$. V. cholerae strains in the CT1 group exhibited 11 different antibiotic-resistance patterns.
Phenotypic analysis by $\mathrm{PhP}$ is based on 11 biochemical tests. None of the isolates metabolized L-arabinose, cellobiose, gentobiose and sorbitol. Most variation in sugar metabolism was observed when gluconate and amylopectin were used as the substrate (data not shown), suggesting that gluconate and amylopectin may play 
an important role in differentiation of the $V$. cholerae isolates.

Traditional bacterial typing methods based on phenotypic characterization are often regarded as less discriminatory and having a lower level of reproducibility than genotyping. Nevertheless, the present study showed that the PhP system had a higher discriminatory power than ribotyping. PFGE and the PhP system were able to separate the isolates into three distinct groups, suggesting a similar discriminatory power.

$\mathrm{PhP}$ analysis of the isolated strains showed a diversity index of 0.755 . Similar diversity indices (0.7) have been reported by other investigators (Ansaruzzaman et al., 1996) with $V$. cholerae from epidemics. It has been suggested that in epidemics, despite the genetic homogeneity of the isolates, there are some biochemical variations among them (Rahman et al., 2006). This could, in part, be the result of the expression of genes involved in the utilization of sugars, which are usually transient and depend on environmental conditions. Such differences could be detected by the PhP system.

In conclusion, three typing methods, PFGE, ribotyping and $\mathrm{PhP}$, indicated the dissemination of a major $V$. cholerae clone in different provinces in Iran. The PFGE and PhP typing methods, but not ribotyping, were able to distinguish two isolates that were significantly diverse in both genotypic and phenotypic characteristics. Furthermore, our results indicated that continuous monitoring of the prevalence of $V$. cholerae strains could be done with a simple, cost-effective and highly discriminatory RAPD technique.

\section{ACKNOWLEDGEMENTS}

We are grateful to Dr Soroush and Dr Zahraei for collecting and shipping samples. This research was supported, in part, by funds from the Pasteur Insitute of Iran (grant no. 275). Also, special thanks is extended to Dr François-Xavier Weill, Centre National de Référence des Salmonella, Institut Pasteur, Paris, for helping us perform PFGE.

\section{REFERENCES}

Amita, Chowdhury, S. R., Thungapathra, M., Ramamurthy, T., Nair, G. B. \& Ghosh, A. (2003). Class I integrons and SXT elements in El Tor strains isolated before and after 1992 Vibrio cholera O139 outbreak, Calcutta, India. Emerg Infect Dis 9, 500-502.

Ansaruzzaman, M., Albert, M. J., Kühn, I., Faruque, S. M., Siddique, A. K. \& Molby, R. (1996). Differentiation of Vibrio cholerae O1 isolates with biochemical fingerprinting and comparison with ribotyping. J Diarrhoeal Dis Res 14, 248-254.

Chen, C. H., Shimada, T., Elhadi, S., Radu, S. \& Nishibuchi, M. (2004). Phenotypic and genotypic characteristics and epidemiological significance of $c t x^{+}$strains of Vibrio cholerae isolated from seafood in Malaysia. Appl Environ Microbiol 70, 1964-1972.

Dalsgaard, A., Forslund, A., Serichantalergs, O. \& Sandvang, D. (2000). Distribution and content of class 1 integrons in different
Vibrio cholerae O-serotype strains isolated in Thailand. Antimicrob Agents Chemother 44, 1315-1321.

Farmer, J. \& Hickman-Brenner, F. (1992). The genera Vibrio and Photobacterium. In The Prokaryotes: a Handbook on the Biology of Bacteria: Ecophysiology, Isolation, Identification, Applications, vol. 6, pp. 2952-3011. Edited by A. Balows, H. G. Truper, M. Dworkin, W. Harder \& K. H. Schleifer. New York: Springer.

Faruque, S. M., Albert, M. J. \& Mekalanos, J. J. (1998). Epidemiology, genetics and ecology of toxigenic Vibrio cholerae. Microbiol Mol Biol Rev 62, 1301-1314.

Garg, P., Chakraborty, S., Basu, I., Datta, S., Rajendran, K., Bhattacharya, T., Yamaski, S., Bhattacharya, S. K., Takeda, Y. \& other authors (2000). Expanding multiple antibiotic resistance among clinical strains of Vibrio cholerae isolated from 1992-7 in Calcutta, India. Epidemiol Infect 124, 393-399.

Garg, P., Sinha, S., Chakraborty, R., Bhattacharya, S. K., Nair, G. B., Ramamurthy, T. \& Takeda, Y. (2001). Emergence of fluoroquinoloneresistant strains of Vibrio cholerae O1 biotype El Tor among hospitalized patients with cholera in Calcutta, India. Antimicrob Agents Chemother 45, 1605-1606.

Hochhut, B., Lotfi, Y., Mazel, D., Faruque, S. M., Woodgate, R. \& Waldor, W. K. (2001). Molecular analysis of antibiotic resistance gene clusters in Vibrio cholerae O139 and O1 SXT constins. Antimicrob Agents Chemother 45, 2991-3000.

Iwanaga, M., Yamamoto, K., Higa, N., Ichinose, Y., Nakasone, N. \& Tanabe, M. (2000). Tetracycline resistant and polymyxin B sensitive Vibrio cholerae $\mathrm{O} 1 \mathrm{El}$ Tor isolated from the recent epidemics. Jpn J Trop Med Hyg 28, 15-18.

Killgore, G. E. \& Kato, H. (1994). Use of arbitrary primer PCR to type Clostridium difficile and comparison of results with those by immunoblot typing. J Clin Microbiol 32, 1591-1593.

Kondo, S., Kongmuang, U., Kalnauwakul, S., Matsumoto, C., Chen, H. H. \& Nishibuchi, M. (2001). Molecular epidemiologic analysis of Vibrio cholerae O1 isolated during the 1997-8 cholera epidemic in southern Thailand. Epidemiol Infect 127, 7-16.

Kühn, I., Brauner, A. \& Möllby, R. (1990). Evaluation of numerical typing systems for Escherichia coli using the API50CH and the PhPEC systems as models. Epidemiol Infect 105, 521-531.

Lan, R. \& Reeves, P. R. (1998). Recombination between rRNA operons created most of the ribotype variation observed in the seventh pandemic clone of Vibrio cholerae. Microbiology 144, 1213-1221.

NCCLS (2001). Performance Standards for Antimicrobial Susceptibility Testing, 11th informational supplement. Wayne, PA: National Committee for Clinical Laboratory Standards.

Popovic, T., Bopp, C., Olsvik, O. \& Wachsmuth, K. (1993). Epidemiological application of a standardized ribotype scheme for Vibrio cholerae O1. J Clin Microbiol 31, 2474-2484.

Pourshafie, M. R., Grimont, F., Saifi, M. \& Grimont, P. A. D. (2000). Molecular epidemiological study of Vibrio cholerae isolates from infected patients in Teheran, Iran. J Med Microbiol 49, 1085-1090.

Pourshafie, M. R., Grimont, F., Kohestani, S. \& Grimont, P. A. D. (2002). A molecular and phenotypic study of Vibrio cholerae in Iran. J Med Microbiol 51, 392-398.

Rahman, M., Bhuiyan, N. A., Kuhn, I., Ramamurthy, T., Rahman, M., Mollby, R. \& Nair, G. B. (2006). Biochemical fingerprinting of Vibrio parahaemolyticus by the PhenePlate system: comparison between pandemic and non- pandemic serotypes. Epidemiol Infect 134, 985-989.

Sack, D. A., Sack, B. R., Nair, G. B. \& Siddique, A. K. (2004). Cholera. Lancet 363, 223-233.

Thompson, F. L., lida, T. \& Swings, J. (2004). Biodiversity of vibrios. Microbiol Mol Biol Rev 68, 403-431. 